\title{
Shocked to Happy: Experiences of Iranian Diabetics in Reaction to the Bad News of the Diagnosis
}

\author{
Hossein Namdar Areshtanab ${ }^{1}$, Hossein Karimi Moonaghi², Maryam Vahidi', \\ Leila Jouybari ${ }^{4}$, Amir Emami Zeydi ${ }^{5}$, Hossein Ranjbar ${ }^{6}$ \\ ${ }^{1}$ Department of Mental Health and Psychiatric Nursing, Nursing and Midwifery Faculty, \\ Tabriz University of Medical Sciences, Tabriz, IR Iran \\ ${ }^{2}$ Department of Medical Surgery, Faculty of Nursing and Midwifery, Mashhad University of Medical Sciences, \\ Mashhad, IR Iran \\ ${ }^{3}$ Department of Mental Health and Psychiatric Nursing, Nursing and Midwifery Faculty, \\ Tabriz University of Medical Sciences, Tabriz, IR Iran \\ ${ }^{4}$ Department of Child and Family Health, School of Nursing and Midwifery, \\ Golestan University of Medical Sciences, Gorgan, IR Iran \\ ${ }^{5}$ Department of Medical Surgical Nursing, School of Nursing and Midwifery, \\ Mazandaran University of Medical Sciences, Sari, IR Iran \\ ${ }^{6}$ Department of Nursing, School of Nursing and Midwifery, Torbat Heydariyeh University of Medical Sciences, \\ Torbat Heydariyeh, IR Iran
}

\section{SUMMARY}

Diagnosis of a chronic disease like type 2 diabetes mellitus (T2DM) is frequently shocking for patients, which influences their lives. Getting aware of bad news such as obtaining a chronic illness diagnosis is a sensitive issue in patients' lives. Conversely, reactions to the reception of a diagnosis of diabetes are often varied for a few reasons. To manage the diseases through care planning, the identification and modification of the causes of various reactions are necessary. The aim of the present survey was to investigate the reaction of diabetics to the reception of diabetes diagnosis and its possible reasons. In this qualitative study, in-depth interviews were used. Furthermore, traditional content analysis of semi-structured interviews was conducted using a qualitative strategy with 20 individuals with type 2 diabetes. The purposeful sampling approach was employed for recruiting the participants. Eleven male and nine female participants having type 2 diabetes had been transferred to the diabetes association of Iran for receiving consulting assistance in the areas of nutrition, psychology, and health care. Four categories of reactions have arisen from the investigation including behavioral, emotional, contextual, and cognitive reactions. Reactions to the prognosis of diabetes may be different for some reasons. The findings of the present investigation may be employed by health care providers to obtain a more comprehensive understanding of unusual and usual reactions, their causes, and the context in the early years after the diagnosis and planning care programs for disease management.

Key words: diabetes mellitus, diagnosis, emotion, qualitative research 
Corresponding author:

Hossein Namdar Areshtanab

e-mail: hna442000@yahoo.com

\section{INTRODUCTION}

As one of the most common and serious chronic illnesses of the current century, diabetes mellitus has been known as an increasing menace to the world's public health (1). In 2014, the world prevalence was estimated to be $9 \%$ among adults aged over 18 years. In 2019, diabetes was the ninth leading cause of death with an estimated 1.5 million deaths directly caused by diabetes (2). Type 2 diabetes mellitus (T2DM) is covering over $90 \%$ of all cases (3). Most recent cases with diabetes are from developing countries and it appears that the Middle East is among the areas that will have the biggest enhancement within the prevalence of diabetes by 2030. Based on the research results, the prevalence of $\mathrm{T} 2 \mathrm{DM}$ is $8.7 \%$ in Iranians (4). The prognosis of a serious disease, including diabetes, may cause an immensely stressful and uncomfortable experience (5). Most of the investigations on the new cases of diabetes mainly concentrated on subjects' emotional consequences and, particularly, on negative consequences after receiving the diagnosis. Few studies have focused on the unusual emotional outcomes, their cause, cognitive and behavioral outcomes in the early years after the diagnosis, and how they manage their illness in the first year after receiving the diagnosis $(6,7)$. The investigations conducted in western communities that differ in terms of social and cultural histories from the Iranian community are provided in the reviewed literature. Furthermore, based on the results of the investigations, sociocultural context may impact on emotional, behavioral, and cognitive outcomes of illness $(8,9)$. Nurses, when taking care of diabetes, should avoid the focus on the disease but rather focus on the patient, because this diagnosis can be the cause of various emotions that make it difficult to adapt to the lifestyle that comes after the diagnosis. Thus, it is important that the emotions produced and their causes after the confirmation of the diagnosis are heard and evaluated, so that the patient can accept the disease and adhere to treatment in a participative style (10). Therefore, understanding the outcomes and how to manage them to provide effective care is important for health care providers.

\section{A IM}

The aims of the study was to investigate how diabetics react to the diagnosis of diabetes and its causes.

\section{METHODS}

\section{Design}

According to qualitative semi-structured interviews with traditional content study, the research was planned as qualitative research. The qualitative content analysis techniques derived from Graneheim and Lundman were employed to analyze the data (11). The study first concentrated at each interview to get an idea of the individuals' experience. Next, the units of significance, which were words, aspects of the participants' experience, were highlighted, and condensed to make the text shorter with preserving the content. Next, the content condensed meaning was extracted from each interview transcript. Finally, through comparison, reflection and interpretation, these codes were classified and subclassified by the authors.

\section{Setting and sample characteristics}

A purposive sample of twenty cases was obtained. Subjects were chosen according to the following inclusion criteria: verified diagnosis of type 2 diabetes mellitus for at least two years, knowledge of the diagnosis, and physical and cognitive capability for participation. Data collection was conducted through in-depth, semi-structured, and one-on-one interviews administrated between September 2013 and August 2014. The individuals (11 men and 9 women) with type 2 diabetes had been referred to the Diabetes Association of Iran for receiving con- 
sulting services in the field of psychology, health care, and nutrition. It offers wide-ranging, specialized, multidisciplinary services for outpatient referred by the doctor or nurse specialized in diabetes, six days every week during the morning shifts. Among others, 17 private interviews were conducted at the discretion of participants regarding location and time by the Iran Diabetes Association, Tabriz branch, and three of the interviews were conducted in a private room within the Tabriz Faculty of Nursing and Midwifery.

\section{Ethical considerations}

The investigation was confirmed by the Ethics Committee of the Mashhad University of Medical Sciences (no. 900603). Verbal and written information about the investigation was provided for the participants. Informed written consent was achieved from all individuals. Individuals participated voluntarily, and confidentiality and anonymity of the participants' identities were considered during the investigation and all publications. The location and time of the analysis were selected by the agreement of the individuals. The objective of the study was restated to the individuals by the corresponding author and they were allowed to withdraw from the research at any time, in line with the Declaration of Helsinki.

\section{Data collection and analysis}

The qualitative interviews were carried out in Persian by the corresponding author.

The interviews were conducted only one time for each individual. According to the objective of the study, the analyses were carried out in Persian and translated into English. The questions were about their experiences of facing and living with the disease. The interviews were tape-recorded and transcribed verbatim. The time for the first set of interviews was 60 - 80 minutes, while the last series continued for 40 - 50 minutes, (the average time of each interview was 45 minutes). Data collection lasted until the achievement of data saturation i.e. data collection continued till no new code was evident from data analysis. The analyses of the inter- view texts started after the first interview have been performed and transcribed. Lincoln and Guba's criteria regarding improving the precision of qualitative investigations (1985) through transferability, credibility, confirmability, and dependability were proposed (12). During the analysis process, sufficient time was devoted by the investigators to collect the data and maintained close communication with the research individuals. The interviews were rechecked by participant's concordance precisely describing the ideas of the subjects.

Data coding and categorization were independently conducted by the authors, and comparison was made between emergent themes. Ideas of peer reviewers including specialists and three Ph.D. nominees of nursing in data analysis were employed, and cases were analyzed during the two weeks. Concerning precision, the results were reviewed and evaluated by the investigation team until reaching an agreement. The data (HN) were collected and investigated by one researcher and qualitative analysis was discussed, checked, and verified by two experts (HKM, LJ, MV). The credibility of the data was improved by such reviews. The data were collected and discussed by one researcher while others checked and validated the findings for increasing the dependability. According to the data collected from individuals and memos of interviews analyzed, participants were selected through different variations including age, background experience with the disease, the economic status of the family, educational status, career background, and necessity of daily injectable insulin to produce transferability. Samples of interview questions included:

1. How did you feel when you found out that you had diabetes?

2. What did you think about the causes of the reactions?

3. What did follow the definitive diagnosis?

\section{RESULTS}

Most of the individuals were male, married, and with a positive family history (Table1).

Four categories of reactions revealed by the investigation included cognitive, emotional, behavioral, and contextual reactions (Table 2). 
Table 1: Clinical and socio-demographic properties of individuals

\begin{tabular}{|c|c|c|c|c|c|c|c|}
\hline $\begin{array}{c}\text { Age: } \\
\text { Mean } \pm \text { SD }\end{array}$ & $\begin{array}{c}\text { Sex } \\
\text { No }(\%)\end{array}$ & $\begin{array}{c}\text { Marital status } \\
\text { No }(\%)\end{array}$ & $\begin{array}{c}\text { Employment } \\
\text { No (\%) }\end{array}$ & $\begin{array}{c}\text { Education level } \\
\text { no. }(\%)\end{array}$ & $\begin{array}{c}\text { Type of treatment } \\
\text { No., }(\%)\end{array}$ & $\begin{array}{l}\text { Duration of } \\
\text { diabetes }\end{array}$ & $\begin{array}{l}\text { Family } \\
\text { history }\end{array}$ \\
\hline $47.8 \pm 12.0$ & \begin{tabular}{|l} 
Male: \\
11 (55\%) \\
Female: \\
$9(45 \%)$
\end{tabular} & $\begin{array}{c}\text { Married: } \\
19(95 \%) \\
\text { Single: } \\
1(5 \%)\end{array}$ & $\begin{array}{c}\text { Unemployed: } \\
3(15 \%) \\
\text { Employed:7 (35\%) } \\
\text { Retired:6 (30\%) }\end{array}$ & \begin{tabular}{|c|} 
Illiterate to \\
under diploma: \\
$8(40 \%)$ \\
Diploma: \\
$6(30 \%)$ \\
Graduate: \\
$6(30 \%)$ \\
\end{tabular} & \begin{tabular}{|c} 
Oral medication \\
$10(50 \%)$ \\
Insulin and \\
medications \\
$10(50 \%)$
\end{tabular} & $10.26 \pm 7.07$ & $\begin{array}{c}\text { Yes: } \\
11(55 \%) \\
\text { No: } \\
9(45 \%)\end{array}$ \\
\hline
\end{tabular}

Table 2: Thematic matrix of categories, subcategories and concepts

\begin{tabular}{c|l|l}
\hline \hline Categories & Subcategories & Concept \\
\hline $\begin{array}{c}\text { Emotional } \\
\text { reactions }\end{array}$ & Usual & Denial and protest, blame, anger, crying, anxiety $(\mathrm{n}=18)$ \\
\hline $\begin{array}{c}\text { Cognitive } \\
\text { reactions }\end{array}$ & Pnusual & Happiness and apathy $(\mathrm{n}=2)$ \\
\cline { 2 - 3 } $\begin{array}{c}\text { Behavioral } \\
\text { reactions }\end{array}$ & Pegative (primary) & Optimism $(\mathrm{n}=1)$ \\
\cline { 2 - 3 } & $\begin{array}{l}\text { Negative behavioral } \\
\text { coping }\end{array}$ & $\begin{array}{l}\text { Fear, meaningless }(\mathrm{n}=18) \\
\text { (n }=15)\end{array}$ \\
\hline \multirow{2}{*}{$\begin{array}{c}\text { Contextual } \\
\text { factors }\end{array}$} & Individual factors & $\begin{array}{l}\text { Participants' prior beliefs about diabetes, prior knowledge } \\
\text { about diabetes }(\mathrm{n}=18)\end{array}$ \\
\cline { 2 - 3 } & Family factors & $\begin{array}{l}\text { Former experience with a family member with the disease, } \\
\text { and family members' reaction to the diagnosis }(10)\end{array}$ \\
\hline \hline
\end{tabular}

\section{Emotional responses}

After receiving the news of the diagnosis, most of the participants showed emotional reactions such as denial and protest, blame, anger, crying, anxiety, happiness, and apathy.

"After the doctor told me that I've got diabetes, I was shocked and I felt my world was destroyed." (Male, 42 years old)

"When I received the news of diabetes diagnosis, I was surprised and said to myself 'Why me?'. ‘Why now? Why diabetes?" (Male, 55 years old)

"I visited an ophthalmologist for my eye problems. After the examination, the doctor required doing the blood test and after obtaining the test results, he told me that I had diabetes. I felt speechless and started to cry." (Woman, 45 years old)

"When I visited a family doctor due to poly- dipsia and polyuria, after examination, the doctor told me that I had diabetes. I told the doctor he was wrong, and such a thing was impossible and could not be true." (Man, 41 years old)

It refers to the participants' cognitive responses associated with receiving news of the diagnosis.

\section{Cognitive responses}

Participants' cognitive responses are associated with receiving the news of the diagnosis, including the surprise of disease diagnosis despite the suitable physical activity, fear of disease complications and their concerns about the future. The expressed causes by participants are the primary determinants of one's feelings and actions in response to the reception of the news of the diagnosis. 
"After the doctor told me I had diabetes, I was shocked and felt that my world collapsed." (Female, 60 years old)

"I had periods of fatigue and weakness. I heard that those who have cancer may have these symptoms. When the doctor said that I had diabetes, I got happy and thanked God that I didn't have cancer." (Male, 52 years old)

"After the doctor told me that I had diabetes, I was indifferent without any specific reaction because I did not know of the character of the disease." (Male, 45 years old)

"When the doctor told me that I had diabetes, I was afraid of being badly judged and marked by my husband and his family." (Female, 30 years old)

"After the doctor told me that I had diabetes was upset and depressed thinking of eventually becoming crippled and blind." (Male, 40 years old)

\section{Behavioral responses}

Most participants, after receiving the news of the diagnosis, demonstrated behavioral reactions such as visiting another doctor for the confirmation of the diagnosis, accepting the disease, seeking information about diabetes, and carrying initial selfmanagement activities, including daily blood glucose control, diet, and exercise, and taking prescribed medications.

"After examination and tests, the doctor said that I had diabetes. I said 'maybe he is wrong' and I visited another doctor. He also confirmed the previous diagnosis." (Male, 55 years old)

"After examination and tests, the doctor said that I had diabetes. I was devastated. I felt frustrated and broken. Even now, I am crying when I recall that moment". (Female, 50 years old)

"I searched the causes of diabetes on the internet and I found that one of the causes can be a poor lifestyle" (Female, 35 years old, high educational level)

"After injecting the insulin, I eat my breakfast and do housework. After a while, I feel tired and take a rest. For lunch, I prepare and eat an appropriate meal. In the evening, after a short rest, I go for a walk providing the weather is good. (Female, 43 years old)

"After receiving the diagnosis of diabetes, I took care of myself and lost ten kilos in three months through exercise and regulating the diet. I control my blood glucose daily". (Female, 48 years old)

\section{Contextual factors}

Contextual factors such as a former experience with a family member diagnosed with the disease, participants' prior beliefs about diabetes, prior knowledge about diabetes, and family members' reaction to the diagnosis of diabetes can influence the reaction when receiving the diagnosis of diabetes.

"Because both my father and my mother were diabetic and had hereditary diabetes, I expected that in the future I may also have diabetes. I was slightly upset when I learned that I had diabetes." (Woman, 44 old)

"Because I believed that having diabetes means death, I was shocked when I learned that I had diabetes". (Woman 64 old)

"After receiving the news of diabetes, I did not show any reaction because I did not comprehend diabetes." (Man, 64 old)

"After my husband received the news of diabetes diagnosis about me, he was shocked and upset and was confused about what to do". (Woman 43 old)

"I already knew that diabetes is hereditary. On the other hand, my sister and my brother had diabetes and I expected to develop diabetes. When the doctor told me that I had diabetes I was not very upset. (Man, 58 old)

\section{DISCUSSION}

Receiving the diagnosis of diabetes may cause varying and substantial emotional responses to individuals. In this study, participants had different emotional reactions starting from being shocked to showing apathy and happiness after receiving the diagnosis. Some studies indicate that the sudden onset of chronic disease diagnosis usually causes combined psychological reactions, including shock, anxiety, denial, protest, and anger $(13,14)$. Most of the reactions were viewed as self-protection toward the reduction of the chronicity, the consequences, and the magnitude related to the chronic illness. Patients chose to deny or minimize their disease while managing this problem, specifically when the 
consequences are complex and uncontrollable (15). Researches have indicated that cognitive processing plays a very important role in initial self-management (16). As for the cognitive process, the causes mentioned by participants are the essential indicators of one's feelings and reactions in response to the reception of diagnosis. These reactions presumably resemble an absence of prior knowledge about the disease, previous experience with illness in the family, the expectation of more severe disease than diabetes, fear of disease transmission to children, death due to diabetes, diabetic labeling and stigmatization, and insulin injection. In other studies, except happiness, the reactions of participants receiving the diagnosis and its causes are almost identical to those recorded in this study $(13,17-21)$. Regarding the emotional reactions of happiness after hearing the news of the diagnosis, no similar study was found.

As for behavioral reactions, after receiving the diagnosis, patients began to get information about diabetes from various resources to manage the problem. Most participants have little or false information about their disease. Over time, they get the correct information which lead to the involvement of the individual in the process of decision making, understanding of the status of their health and managing the disease (22 - 24). After obtaining information about diabetes, initial self-management behaviors are shown to manage or decrease the effect of the disease on daily life (25). According to the selfregulatory model, an individual's reaction to disease is based on understanding the disease (26). In this study, the behavioral reactions are more focused on compliance with diet, taking prescribed medications, appropriate physical activities, and blood glucose control. In other studies, the activity of diabetic patients in daily blood glucose measurements, diet food, and taking prescribed medications are expressed as their daily management $(27,28)$. Also, contextual factors, such as former experience with a family member with the illness, participants' prior beliefs about diabetes, prior knowledge about the disease, and family members' reaction to the diagnosis of diabetes can influence the reaction. In other studies, beliefs about the illness and the sociocultural context affected diabetes self-management $(29,30)$. Based on Bandura's theory, the environment affects an individual's beliefs, skills, and knowledge re- sulting in the individual's actions. The atmosphere created by the family of the patient with diabetes plays a major role in the patient's reaction to the illness and the following control of that illness (31). According to the Common Sense Self-Regulatory Model, individuals develop emotions and beliefs about the disease, including five dimensions. These cognitions are the perception of the label and symptoms of the disease, duration of the disease, outcomes, and perceptions of the cause of the disease, and perceptions of controllability. The management of health threats, the diagnosis of the disease, and health information can be facilitated by such dimensions (32).

\section{Strengths and limitations}

In-depth interviewing with a wide variety of individuals with 2 type diabetes is considered as a unique strength of the present investigation. We permitted individuals to bring up important issues which cannot be obtained by a quantitative questionnaire-based survey. The participants were selected from various demographic and clinical areas with a wide variety of several experiences of reaction toward receiving the diagnosis. In the present survey, the sample size is small and done in specific cultural context. Additionally, the findings simply mirror the view of patients regarding reactions to having diabetes. Therefore, according to similar qualitative investigations, the findings must be generalized with caution for Iran or other countries. Moreover, input data from both families and health care providers are required for future research. To the best of our knowledge, a population-based study is essential for verifying such results.

\section{CONCLUSION}

The results of this study showed that reactions to the diagnosis of diabetes in patients can be diverse, ranging from shock to happiness. Furthermore, the type of these reactions is associated with the individual context. The results of the present research are utilized by nurses to obtain a more comprehensive understanding of unusual and usual reactions, their causes, especially in the early years after receiving the diagnosis in order to plan care programs for disease management. 


\section{Acknowledgment}

The researchers want to appreciate the vicechancellor on research in Mashhad University of Medical Sciences for supporting this investigation and also appreciate all participants and great cooperation of Tabriz branch Diabetes Association for their excellent assistance in performing this survey.

\section{Competing interest}

The researchers state that they have no conflict of interest.

\section{References}

1. TuncayT, Musabak I, Gok DE et al. The relationship between anxiety, coping strategies and characteristics of patients with diabetes. Health and quality of life outcomes 2008;(16):1-9. https://doi.org/10.1186/1477-7525-6-79

2. World Health Organization, 2017. Fact sheetsdiabetes: Key facts. Available at (accessed 5.9.2018):

https://www.who.int/en/news-room/factsheets/detail/diabetes

3. Olhansky E, Sacco D, Fitzgerald $\mathrm{K}$ et al. Living with diabetes: normalizing the process of managing diabetes. The Diabetes Educator 2008; (34):1004-1012.

https://doi.org/10.1177/0145721708327304

4. Harati H, Hadaegh F, Saadat N et al. Populationbased incidence of Type 2 diabetes and its associated risk factors: results from a six-year cohort study in Iran. BMC Public Health 2009; (9):186. https://doi.org/10.1186/1471-2458-9-186

5. Barskova T, Oesterreich R. Post-traumatic growth in people living with a serious medical condition and its relations to physical and mental health: a systematic review. Disability and rehabilitation $2009 ;$; (31):1709-1733. https://doi.org/10.1080/09638280902738441

6. Thoolen B, Ridder DD, Bensing J, Gorter $\mathrm{K}$ et al. No worries, no impact? A systematic review of emotional, cognitive, andbehavioural responses to the diagnosis of type 2 diabetes. Health Psychology Review 2008;(2):65-93.

https://doi.org/10.1080/17437190802311361

7. Peel E, Parry O, Douglas $\mathrm{M}$ et al. Diagnosis of type 2 diabetes: a qualitative analysis of patients' emotional reactions and views about information provision. Patient education and counseling 2004;(53):269-75.

https://doi.org/10.1016/j.pec.2003.07.010

8. Rovner BW, Casten RJ, Harris LF. Sociocultural influences on diabetes self-management behaviors in older African Americans.Diabetes spectrum 2013; (26): 29-33. https://doi.org/10.2337/diaspect.26.1.29

9. Patel NR, Chew-Graham C, Bundy C et al. Illness beliefs and the sociocultural context of diabetes 
self-management in British South Asians: a mixed methods study. BMC Fam Pract. 2015;(16):58. https://doi.org/10.1186/s12875-015-0269-y

10. Ferreira DSP, Daher D Teixeira ER et al. Emotional impact before the diagnosis of type 2 Diabetes Mellitus. UERJ Nursing Journal. 2013;21(1):41-46.

11. Graneheim UH, Lundman B. Qualitative content analysis in nursing research: concepts, procedures and measures to achieve trustworthiness. Nurse EducationToday $2004 ;(24): 105-112$. https://doi.org/10.1016/j.nedt.2003.10.001

12. Denzin NK, Lincoln YS. The Sage Handbook of Qualitative Research. Sage publication, Washigton DC, USA, $4^{\text {th }}$ edition. 2011:108.

13. Al-Amer R, Ramjan L, Glew P, Salamonson Y. Diagnosis of Type 2 Diabetes: The Experience of Jordanian Patients with Co-existing Depression. Issues Ment Health Nurs. 2015; 36(3):231-8. https://doi.org/10.3109/01612840.2014.960627

14. Collins S, Reynolds F. How do adults with cystic fibrosis cope following a diagnosis of diabetes? J Adv Nurs.2008;64(5):478-87. https://doi.org/10.1111/j.1365-2648.2008.04797.x

15. Charmaz K, Good days, bad days: the self in chronic illness and time.New Brunswick, NJ: Rutgers University Press.1991:134-167.

16. Kashdan TB, KaneJQ. Posttraumatic distress and the presence of posttraumatic growth and meaning in life: Experiential avoidance as a moderator. Personality and individual differences 2011; 50(1): 84-89. https://doi.org/10.1016/j.paid.2010.08.028

17. Handley J, Pullon S, Gifford H. Living with type 2 diabetes: 'Putting the person in the pilots' seat'. Aust J Adv Nurs. 2010;27(3): 12-19.

18. Wang HF, Yeh MC. Psychological resistance to insulin therapy in adults with type 2 diabetes: mixed-method systematic review. J Adv Nurs. 2012; 68:743-57.

https://doi.org/10.1111/j.1365-2648.2011.05853.x
19. Gillibrand W, Flynn M. Forced externalization of control in people with diabetes: a qualitative exploratory study. J Adv Nurs.2001; 34, 501-10. https://doi.org/10.1046/j.1365-2648.2001.01779.x

20. Beeney LJ, Bakry AA, Dunn SM. Patient psychological and information needs when the diagnosis isdiabetes. Patient Educ Couns. 1996; 29, 109-16.

https://doi.org/10.1016/0738-3991(96)00939-1

21. Péres DS, Franco LJ, dos Santos MA. Feelings of women after the diagnosis of type 2 diabetes.Rev Lat Am Enfermagem. 2008; 16(1):101-8. https://doi.org/10.1590/S0104-11692008000100016

22. Rimal RN, Flora JA, Schooler C. Achieving improvements in overall health orientation effects of campaign exposure, information seeking, and health media use. Communication Research, 1999; 26, 322-48.

https://doi.org/10.1177/009365099026003003

23. Cutilli CC. Seeking health information: what sources do your patients use? Orthopedic nursing, 2010; 29, 214-9.

https://doi.org/10.1097/NOR.0b013e3181db5471

file:///C:/Users/win10/Downloads/10.1097@NOR.0

b013e3181db5471.pdf

24. Wilson TD. Information behaviour: an interdisciplinary perspective. Information processing \& management 1997; 33, 551-72. https://doi.org/10.1016/S0306-4573(97)00028-9

25. Audulv A, Norbergh KG, Asplund K. et al. An ongoing process of inner negotiation-a Grounded Theory study of self-management among people living with chronic illness. Journal of nursing and healthcare of chronic illness, 2009; 1, 283-93. https://doi.org/10.1111/j.1752-9824.2009.01039.x

26. Hale ED, Treharne G, Kitas G. The CommonSense Model of self-regulation of health and illness: how can we use it to understand and respond to our patients' needs? Rheumatology, 2007;46,904-6.

https://doi.org/10.1093/rheumatology/kem060 
27. Thorne S, Paterson B, Russell C. The structure of everyday self-care decision making in chronic illness. Qualitative health research, 2003; 13:1337-52. https://doi.org/10.1177/1049732303258039

28. Ellison GC, Rayman KM. Exemplars' experience of self-managing type 2 diabetes. The Diabetes Educator, 1998;24:325-30.

https://journals.sagepub.com/doi/10.1177/0145721 $\underline{79802400307}$

https://doi.org/10.1177/014572179802400307

29. Patel NR, Chew-Graham C, Bundy $C$ et al.. Illness beliefs and the sociocultural context of diabetes self-management in British South Asians: a mixed methods study.
BMC FAM Pract.2015; 10; 16:58.

30. Chase HP, Maahs DM. Understanding diabetes: A handbook for People Who Are Living With Diabetes. Children's Diabetes Foundation publishing, USA. $12^{\text {th }}$. edith. 2011.

31. Bandura, A. Health promotion by social cognitive means. Health Education\&Behavior, 2004; 31(2), 143-164.

https://doi.org/10.1177/1090198104263660 


\title{
Od šoka do sreće: Iskustva iranskih dijabetičara u reakciji na loše vesti o dijagnozi
}

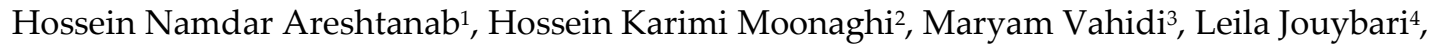 \\ Amir Emami Zeydi ${ }^{5}$, Hossein Ranjbar ${ }^{6}$ \\ ${ }^{1}$ Departman za mentalno zdravlje i psihijatrijsko sestrinstvo, Fakultet za sestrinstvo $i$ akušerstvo, \\ Univerzitet medicinskih nauka u Tabrizu, Tabriz, Islamska republika Iran \\ ${ }^{2}$ Departman za medicinsku hirurgiju, Fakultet za sestrinstvo i akušerstvo, Univerzitet medicinskih nauka u Mašhadu, \\ Mašhad, Islamska republika Iran \\ ${ }^{3}$ Departman za mentalno zdravlje i psihijatrijsko sestrinstvo, Fakultet za sestrinstvo i akušerstvo, \\ Univerzitet medicinskih nauka u Tabrizu, Tabriz, Islamska republika Iran \\ ${ }^{4}$ Departman za zdravlje deteta i porodice, Fakultet za sestrinstvo i akušerstvo, Univerzitet medicinskih nauka u Golestanu, \\ Gorgan, Islamska Republika Iran \\ ${ }^{5}$ Departman za medicinsku hirurgiju u sestrinstvu, Fakulteat za sestrinstvo i akušerstvo, \\ Univerzitet medicinskih nauka u Mazandaranu, Sari, Islamska Republika Iran \\ ${ }^{6}$ Departman za sestrinstvo, Fakultet za sestrinstvo i akušerstvo, Univerzitet medicinskih nauka Torbat Heydariyeh, \\ Islamska republika Iran
}

\section{S AŽETAK}

Dijagnoza hronične bolesti poput dijabetesa melitusa tipa 2 je često šokantna za pacijente, što utiče na njihove živote. Svesno prihvatanje loših vesti kao što je dobijanje dijagnoze o hroničnoj bolesti je veoma osetljiva tema u životu pacijenata. Reakcije na dobijanje dijagnoze dijabetesa se razlikuju iz nekoliko razloga. Lečenje bolesti kroz planiranje nege, identifikaciju i modifikaciju uzroka različitih reakcija je neophodno. Cilj ove studije bilo je ispitivanje reakcije dijabetičara na dobijanje dijagnoze dijabetesa $\mathrm{i}$ njenih uzroka. U ovoj kvalitativnoj studiji korišćeni su produbljeni intervjui. Štaviše, tradicionalna anliza sadržaja polustrukturiranih intervjua sprovedena je primenom kvalitativne strategije $\mathbf{u}$ razgovoru sa 20 osoba sa dijabetesom melitusom tipa 2. Pristup ciljanog uzorkovanja primenjen je za regrutovanje učesnika. Jedanaest muškaraca i devet žena sa dijabetesom melitusom tipa 2 prebačeno je u Asocijaciju dijabetičara Irana zbog konsultacija u oblasti ishrane, psihologije i zdravstvene nege. $U$ ispitivanju su zabeležene četiri vrste reakcija, uključujući bihejvioralne, emocionalne, kontekstualne i kognitivne reakcije. Reakcije na prognozu dijabetesa se mogu razlikovati iz nekoliko razloga. Rezultate ove studije mogu koristiti zdravstveni radnici kako bi stekli dublje razumevanje neuobičajenih i uobičajenih reakcija, njihovih uzroka, kao i vremenskog konteksta nakon dobijanaja dijagnoze kao i za planiranje programa lečenja ove bolesti.

Ključne reči: dijabetes melitus, dijagnoza, emocija, kvalitativno istraživanje 